(C) 2019 Solovey. This article is distributed under the terms of CC Attribution-Share Alike 4.0 International as described at https://creativecommons.org/lice$n s e s / b y-s a / 4.0$

UDC: 378.14.015.62

\title{
THE IMPLEMENTATION OF EDUCATIONAL REFORMS IN THE CONTEXT OF GLOBALIZATION AND GLOBAL TRANSFORMATION OF EDUCATION (THE EXPERIENCE OF TURKEY IN THE FIRST QUARTER OF THE 21 ${ }^{\text {st }}$ CENTURY)
}

\author{
Zlata Solovey \\ Postgraduate student, \\ Pereyaslav-Khmelnitsky state pedagogical University \\ named after Hryhoriy Skovoroda, Pereyaslav-Khmelnitsky, Ukraine \\ https://orcid.org/0000-0002-1419-3865; e-mail: zlatasolovei@gmail.com
}

The article deals with the problems of implementation of educational reforms in the conditions of globalization and world transfomation on the example of Turkey. In Turkey, educational reforms are actively carried out. The main objective is to prepare competitive young people for the labor market in their native country and abroad.

According to the conducted analysis of scientific studies on educational reform in Turkey 2012, it is possible to allocate the following principal ways of its successful implementation: the development of preschool education should be one of the first links on the socialization of children and formation of their psychological readiness for learning; internationalization and international cooperation in the field of education as a strategic direction for the development of education; participation at the international projects on independent assessment of the quality of education for an objective analysis of the country's education system and improvement of the content of education, curricula, methods and means of education; promoting the development of vocational education institutions, participate in national and international projects; the development of programs of academic mobility of teachers to share positive experiences with their colleagues from other countries who wish to develop their skills in certain fields of science and participate in international scientific research; promote the development of informal and distance education at all levels; special attention to the formation of entrepreneurial competence of young people; promoting the development of information system of subjects of the educational process and the free access of students to electronic learning resources and ensuring their security in the information space; monitoring the educational achievements of young people and at the same time, the use of ICT to ensure quick receipt of the results of the statistical analysis; promoting the development of new Ukrainian education in rural schools; taking into account the centuriesold traditions of the country (culture, education, religion, etc.), which can not be 
changed in a short time, and should be analyzed and adapted gradually to the world educational trends; consideration and analysis of the problems hindering the process of globalization of education in the country.

Key words: education of Turkey, educational reform, globalization, global transformation of education, reforming education in schools, development of preschool education, use of information and communication technologies (ICT) in schools, development of competence and knowledge.

У статті розглядаються проблеми впровадження осВітніх реформ $b$ умовах глобалізачї та світової трансформачї освіти відповідно до досвіду Туреччини. У Туреччині активно проводяться освітні реформи, основними завданнями яких є підготовка конкурентоспроможної молоді до ринку праці у рідній та будъ-якій крайні світу. Реалізація освітнъої політики навчання протягом усъого життя; надання необхідной освіти Всъому населенню Туреччини для підготовки якісних фрахівиів у будь-якій галузі науки. Міністерство осВіти Туреччини збирається розширити мережу центрів та установ дистанційного навчання для надання Відповідних освітніх послуг для хворих та мігрантів.

Відповідно до проведеного аналізу наукових досліджень з питань реформи освіти в Туреччині 2012 року, можна виділити наступні основні шляхи ї успішної реалізацій: розвиток дошкільної осВіти має бути однією з перших ланок сочіалізачї дітей та формування їх психологічної готовність до навчання; інтернаціоналізація та міжнародне співробітництво у галузі освіти як стратегічний напрям розВитку освіти; участь у міжнародних проектах $з$ незалежного оцінювання якості освіти для об'єктивного аналізу системи освіти краӥни та вдосконалення змісту освіти, навчальних планів, методів та засобів навчання; сприяння розвитку закладів професійної та професійної освіти, участь у начіональних та міжнародних проектах; розробка програм академічної мобільності викладачів для обміну позитивним досВідом з колегами з інших краӥн та студентами, які бажають розвивати свої навички у певних галузях науки та брати участь у міжнародних наукових дослідженнях; сприяти розВитку неформальної та дистанційної освіти на всіх рівнях; особмива увага до фоомування підприємницької компетентності молоді, яка повинна розпочатися вже $b$ початкових иколах, що забезпечує звуження розриву між пропозиціями систем навчання протягом усъого життя та потребами ринку праці (попит та пропозиція); сприяти розвитку інформачійної системи суб'єктів навчально-виховного процесу та вільному доступу учнів до електронних навчальних ресурсів та забезпеченню їх безпеки $b$ інформачійному просторі; моніторинг навчальних досягнень молоді та водночас використання IКТ для забезпечення швидкого отримання результатіВ статистичного аналізу; сприяння розвитку нової украӥнської осъіти $b$ сільських школах (забезпечення сільських шкіл необхідним лабораторним обладнанням, IКТ, підручниками тощо відповідно до вимог інформачійного суспільства); з урахуВанням багатовікових традицій крайни (культура, осВіта, релігія тощо), які неможливо змінити за короткий час, $i$ ïх слід поступово аналізувати та адаптувати до світових освітніх тенденцій. 
Ключові слова: освіта Туреччини, освітня реформа, глобалізачія, глобальна трансформачія осВіти, реформування освіти $b$ школах, розВиток дочкільної освіти, використання $b$ школах інформачійно-комунікачійних технологій (IКT), розвиток компетентності та знанъ.

Introduction. Globalization processes in the world, the active development of technological infrastructure, namely telecommunications, information systems, microelectronics and, in general, information and communication technologies (ICT), significantly contribute to the transformation of education in any country. Special attention should be paid to the study of the process of formation of the modern system of general secondary education in Turkey. The choice is due to the rapid adaptation (modernization and reformation) of the Turkish education system to the requirements of European integration and modern information society (2003-2007).

Problems and implementation of educational reforms was examined by scientists from Turkey Talim Terbiye Kurulu (2005), Resul Cesur and Leyla Mocan (2014), T. Gokmenoglu, C. Clark, E. Kiraz (2016), Başak Kasa, Yasemin Ersöz (2016) etc.

The aim of the article is to analyze the problems of educational reform in Turkey in the context of globalization and global transformation of education in the early $21^{\text {st }}$ century and identify the main ways of implementing these processes in Ukraine.

Discussion. The term «reform» is defined as a process of a radical, long-term transformation of the relevant aspects of public life, state and legal institutions, individual structures and others. Reforms usually change and modernize the form and content of the relevant social relations, without violating their fundamental foundations. In general, the success of reforms depends on their consistency, scientific validity, phasing, etc. (Gorbatenko V. P., 2003). The main thing in the implementation of the reform is a set of measures of the state and society to bring the education system under the relevant political, socio-economic and other requirements.

Scientists identify the following main objectives of reforming the curriculum of Turkey (Talim Terbiye Kurulu, 2005; Turkey's Education Vision 2023):

- to reduce the focus on theoretical education and to promote the development of practical skills of students in accordance with different educational and research activities within the academic disciplines of the general educational institution;

- revise and develop curricula according to eight key competencies, such as mother tongue communication, communication in foreign languages, mathematical competence and knowledge in the field of science and technology, digital competence, social and civic competence, entrepreneurial competence, competence to learn during life, general cultural competence;

- move from a didactic model focused on the teacher, to a constructivist model focused on the student, which is called «student-centered pedagogy»;

- to promote the Informatization of education is to create conditions to meet the information needs of citizens and society through the construction, development, use of information systems, networks, resources and ICT;

- move away from traditional knowledge assessment and introduce authentic assessment to strengthen civic education; 
- to contribute to the implementation of the annual slice of knowledge and competencies of graduates of primary, secondary and senior classes, as well as international independent assessment, which will provide material for the analysis of the state of education, the use of which will help to draw conclusions about making adjustments to the educational activities of teachers and the educational system of the country;

- to introduce courses of a second foreign language of primary school;

- to expand the sphere of religious education; to create a system of student self-government, and to involve high school students in the work of the community.

They pay attention to the following tasks of educational reform defined by experts of the Organization for economic cooperation and development (OECD) (OECD Environmental Performance Reviews, 2008): improving the education system as a source of social mobility, social alignment and competitiveness of young people; productivity of professional activity of teachers, which, first of all, is their constant improvement of skills and abilities to learn during life, and the quality of education in educational institutions of various levels, even if it requires additional costs for education, including teachers salaries, etc. So, improving the quality of education has become a global priority, and a key role in this belongs to teachers because the implementation of successful reforms is carried out through them.

In addition, scientists identify the problem of the introduction of distance elearning (eng. Electronic learning) in general educational institutions of Turkey to support optional training courses, encourage students to study natural and mathematical disciplines, foreign languages, etc., as well as to ensure continuous professional development of teachers on the job. They justify this by the fact that such training can be used in all types of education (formal, informal, non-formal), while providing lifelong learning, despite the time and location of the subjects of training.

The researchers Gokmenoglu, T., Clark, C., \& Kiraz, E., 2016 (Gokmenoglu, T., Clark, C., \& Kiraz, E., 2016) note that one of the significant problems of the educational reform in Turkey is the teachers' constant professional development, the introduction of training for them to study the international experience of improving the quality of education. It is important to analyze such international assessment tools as Progress in International Reading Literature Study, (PIRLS), Trends in International Mathematics and Science Study (TIMSS), an international program of independent testing of students (eng. Programme for International Student Assessment, PISA) and others. These reports outline the main problems of education in a particular country, which should be paid attention to. They can be used to develop educational policy measures aimed at improving the quality of education; development of measures to overcome the existing territorial (village, city, district, etc.) and social (socio-economic and cultural status of students 'families) inequality of educational results; promoting the improvement of the content of mathematical education and the development of programs in mathematics for secondary schools; allocation, analysis and promotion of successful educational practices working in certain social contexts, with a view to their dissemination in educational institutions; evaluation of the quality of teachers teaching activities on the organization of the educational process; organization of measures for the development of professional competence of 
teachers in the framework of training and retraining of management and teaching staff; organization of research on the results of international monitoring of the quality of General education to identify effective strategies to reduce the inequality of educational results in the country; development of measures to support students in complex social contexts, as well as to analyze the content, technology and organizational forms of General education that can improve the quality of General education.

Thus, the ratings of educational institutions in terms of international monitoring of education are a form of benchmarking, which will improve the quality of education in the country.

Scientists Başak Kasa, Yasemin Ersöz (Başak Kasa, Yasemin Ersöz, 2016), analyzing the results of the implementation of the educational reform of 2012 in Turkey, identified the main sub-topics and categories to them to determine the positive and negative aspects of this process, namely:

- the sub-topic «updating the education system» which covers extension of compulsory education to 12 years; changes in the structure of the school; changes in the curriculum;

- the sub-topic «vocational education», which covers early introduction of vocational education; increasing the importance of vocational schools; reducing problems with University entrance examinations; opening religious vocational schools; the choice of pupils between religious education or vocational education options;

- the sub-topic «lowering the age of schooling», which covers early start of education; early start of professional life; early socialization; language development;

- in the negative aspects, the sub-topic «updating the education system», which covers extension of compulsory education to 12 years; changes in the structure of the school; changes in curricula;

- the sub-topic «vocational education», which covers early choice of profession, manuals and textbooks for vocational education, the opening of religious vocational secondary schools;

- the sub-topic «reducing the age of school start», which covers early start of education, insufficient development of abilities and psychological unpreparedness for learning, storage of classes of mixed age groups.

Table 1 presents the positive findings of the analysis of questionnaires of 265 future teachers on the educational reform of Turkey in 2012, in a row, in 2013.

Table 1

\section{Positive conclusions of teachers on educational reform in Turkey in 2012 and, in a row, in 2013}

\begin{tabular}{|l|c|c|l|c|c|}
\hline \multicolumn{1}{|c|}{ Subtopic } & $\mathbf{2 0 1 2}$ & $\mathbf{2 0 1 3}$ & \multicolumn{1}{|c|}{ Categories } & $\mathbf{2 0 1 2}$ & $\mathbf{2 0 1 3}$ \\
\hline $\begin{array}{l}\text { The upgrade } \\
\text { of the } \\
\text { education } \\
\text { system }\end{array}$ & 265 & 65 & $\begin{array}{l}\text { extension of compulsory education } \\
\text { to 12 years }\end{array}$ & 140 & 39 \\
\cline { 3 - 6 } & & & changes in school structure & 74 & 18 \\
\cline { 3 - 6 } & & changes in the curriculum & 51 & 8 \\
\cline { 3 - 6 } & & speech development & 6 & - \\
\hline
\end{tabular}


Continuation of table 1

\begin{tabular}{|c|c|c|c|c|c|}
\hline \multirow[t]{5}{*}{$\begin{array}{l}\text { Professional } \\
\text { education }\end{array}$} & \multirow[t]{5}{*}{141} & \multirow[t]{5}{*}{32} & $\begin{array}{l}\text { early introduction of vocational } \\
\text { education }\end{array}$ & 83 & 13 \\
\hline & & & $\begin{array}{l}\text { the increasing importance of } \\
\text { technical and vocational education } \\
\text { institutions }\end{array}$ & 22 & 15 \\
\hline & & & $\begin{array}{l}\text { the decrease in the problems during } \\
\text { university entry examinations }\end{array}$ & 6 & 2 \\
\hline & & & $\begin{array}{l}\text { opening of religious vocational } \\
\text { schools }\end{array}$ & 12 & 2 \\
\hline & & & $\begin{array}{l}\text { students can choose between } \\
\text { religious education or vocational } \\
\text { education }\end{array}$ & 18 & - \\
\hline \multirow{4}{*}{$\begin{array}{l}\text { Lowering the } \\
\text { age for } \\
\text { starting } \\
\text { school }\end{array}$} & \multirow[t]{4}{*}{75} & \multirow[t]{4}{*}{63} & early education & 40 & 31 \\
\hline & & & early start of professional life & 15 & 20 \\
\hline & & & early socialization & 14 & 12 \\
\hline & & & speech development & 6 & - \\
\hline
\end{tabular}

Scientists, investigating the answers of future teachers to the questionnaire, identified such positive conclusions on the implementation of the training system in Turkey $4+4+4$ (4 years - primary education, 4 years - secondary education or senior level of primary education, 4 years - high school/Lyceum or senior level of secondary education, with the possibility of obtaining, by choice, General secondary education or vocational education), in particular the reform of 2012: twelve-year school will contribute to the updating of curricula; changes in the structure of the school will force teachers to reconsider their methods of teaching academic disciplines and constantly improve professional competence and improve their skills; separation of buildings for primary school and General school to prevent bullying of older students over younger; early introduction of vocational education will allow to see the ability of students in a timely manner, Orient them in; reducing the age of children to enter school (from 6 years to 5 years) will provide an opportunity to accelerate their adaptation to education in General education, which will increase the motivation of students to learn; children who develop faster than others through their individual differences, get the opportunity to start education earlier; reducing the age of children to enter school contributes to the acceleration of their sociallization; early start of education contributes to the early development of the child's speech and logical thinking; increase female students, who were usually in the home form of education.

Table 2 presents the negative findings of 338 future teachers on Turkey's education reform in 2012 and, successively, in 2013. 
Negative conclusions of teachers on the educational reform of Turkey in 2012 and, in a row, in 2013

\begin{tabular}{|c|c|c|c|c|c|}
\hline Subtopic & 2012 & 2013 & Categories & 2012 & 2013 \\
\hline \multirow{3}{*}{$\begin{array}{l}\text { The upgrade } \\
\text { of the } \\
\text { education } \\
\text { system }\end{array}$} & \multirow[t]{3}{*}{338} & \multirow[t]{3}{*}{173} & $\begin{array}{l}\text { extension of compulsory education } \\
\text { up to } 12 \text { years }\end{array}$ & 193 & 113 \\
\hline & & & changes in school structure & 90 & 25 \\
\hline & & & changes in the curriculum & 55 & 35 \\
\hline \multirow{3}{*}{$\begin{array}{l}\text { Professional } \\
\text { education }\end{array}$} & \multirow[t]{3}{*}{48} & \multirow[t]{3}{*}{25} & early career choice & 23 & 13 \\
\hline & & & $\begin{array}{l}\text { manuals and textbooks for } \\
\text { vocational education }\end{array}$ & 23 & 10 \\
\hline & & & $\begin{array}{l}\text { opening of religious vocational } \\
\text { secondary schools }\end{array}$ & 2 & 2 \\
\hline \multirow[t]{3}{*}{ Subtopic } & \multirow[t]{3}{*}{207} & \multirow[t]{3}{*}{214} & early education & 112 & 94 \\
\hline & & & $\begin{array}{l}\text { insufficient development of abilities } \\
\text { and psychological unpreparedness } \\
\text { for learning }\end{array}$ & 82 & 75 \\
\hline & & & classes of mixed age groups & 13 & 45 \\
\hline
\end{tabular}

According to tables 1 and 2, when analyzing the opinions of future teachers who graduated from higher education institutions in 2012, that is, when the Turkish education reform has not yet begun to act fully, and those who answered the questionnaire on this reform in 2013 (the first year of the reform), scientists note that the assessment (338) was more positive (265), in 2013, this statistics has not changed for the better.

Studying the answers of future teachers to the questionnaires, the researchers identified such negative conclusions/problems of the implementation of the education reform in Turkey in 2012: the discrepancy of professional training of teachers in 2012 and 2013 to the requirements of the reform of 2012; the discrepancy of textbooks to the education system, which is proposed in 2012; lack of awareness of subjects of the educational process on the principles, approaches and conditions of education reform; additional pre-school education, which hinders the process of socialization of children; many regions of Turkey are not ready for the introduction of compulsory 12-year education; non-compliance of school equipment with the requirements of the reform, such as the lack of provision of ICT, laboratory equipments, etc.; heavy adaptation of primary school teachers to students who went to school in 5.5 years for the reform of 2012, as their methods and approaches of training are focused on students aged 6-7 years; early start of vocational education can cause disappointment for young people in the future; the creation of an excessive number of professional religious schools may hamper the development of other areas of vocational education for young people in Turkey. 
In addition to the above mentioned, scientists paid attention to the following problems:

$>$ theoretically recognized and approved in the documents the concept of learning, the ability to appreciate different types of abilities of students and notice special needs have not become an integral part of the educational process;

dropout of students (especially among women) at all levels and in all types of education remains high;

$>$ prevailing attitudes in society encourage students to choose «male» and «female» professions, which increases gender segregation in the labor market;

$>$ teachers are not motivated to continuous learning;

$>$ in society, there are still very large differences between the proposals of the system of continuous education and the needs of the labor market, since educational institutions and the labor market do not lead to active cooperation with each other in order to develop continuous training;

$>$ the profession of a teacher is devoid of attractiveness: a small proportion of young people among teachers; there is low competition for pedagogical specialties; after receiving diplomas of teachers, graduates do not go to work in schools, etc.;

$>$ data on the development of the labor market and the economy are not systematic;

$>$ career counseling differs in both quality and accessibility;

> vocational education does not provide decent opportunities for further education and does not prepare for the labor market an adequate number of adequately qualified workers; students access to digital infrastructure and e-learning materials is insufficient and uneven;

$>$ low international academic mobility of students, students and teachers; low level of digital competence of teachers.

Scientists Tuba Gökmenoğlu and Christopher M. Clark (Tuba Gökmenoğlu, Christopher M. Clark, 2015) admit that one of the major problems of the reform of education is the professional development of teachers. They surveyed 460 teachers and analyzed their views on training programmes. As a result of this analysis, the researchers found that the pedagogical experience has a statistically significant impact on the opinions of teachers regarding the participants of the educational process in the framework of the training program, the content of courses, instructtors/Tutors, organization, training centres and evaluation of previous training programs. In addition, the researchers note that for the successful implementation of educational reform, development and evaluation of professional development programs for teachers, it is important to study the problems of primary school teachers involved in the introduction of innovations and prepare students for further education in primary school.

Scientists pay attention to the wishes of the teachers grouped according to needs for professional development that will promote teachers motivation for lifelong learning/learning for life, such as the use of ICT in their professional activities; the use of interdisciplinary relations in the educational process; promote the development of entrepreneurial competence of students; use of project method in the educational process at different levels of education; games teaching methods in the 
teaching of some courses; the solution of problems of inclusive education; teaching gifted children and identifying leaders according to the branches of science that are taught in the General educational institution; forms, methods and means to provide distance e-learning at different levels of education and to promote lifelong learning.

Thus, the implementation of educational reforms in a certain country, in particular Turkey, aimed at the globalization of education in the world, should take into account the traditions of the country (culture, education, religion, etc.), it is not possible and should not change the conditions that contribute to this process (for example, providing schools with information and communication technologies, which should affect the Informatization of education; introduction of training courses for teachers and promotion of their motivation for continuous learning to support the educational process, taking into account the new pedagogical approaches), as well as the conditions hampering the globalization of education in a particular country (for example, the difficult implementation of the policy of reforming education in rural schools, the contradictions between the religious traditions of the country and the General trends of transformation of education in the world, the economic crisis, etc.).

Of particular importance for the reform of education is the constant monitoring of the problems hindering this process, namely, the survey of teachers regarding their wishes and professional needs, according to global trends in the development of education, technological progress, the development of society for correction, editing, additions, and other courses to improve the skills of teachers; analysis of the results of independent testing of students, including international testing programs in comparison with other countries, to clarify the problems associated with curricula and programs, review the content and didactic tasks of textbooks, teaching methods of academic disciplines, etc.

\section{References:}

Gorbatenko V. P. (2003) Reforma. Yuridichnal encyclopedia: In 6 vols. vol. 5. N-P-K, 303.

Talim Terbiye Kurulu (2005) I'lko"g gretim 1-5. sınıf programları tanitım el kitabı. MEB, Ankara. Retrieved from: https://www.medyaokuryazarligi.gov.tr/userfiles/files/program.pdf.

Turkey's Education Vision 2023. Retrieved from: http://2023vizyonu.meb.gov.tr/doc/2023_VIZYON_ ENG.pdf.

OECD Environmental Performance Reviews (2008). OECD Environmental Performance Reviews. Turkey. Retrieved from: http://www.oecd.org/env/country-reviews/environmentalperformancere viewsturkey 2008.htm.

Gokmenoglu, T., Clark, C., \& Kiraz, E. (2016). Professional Development Needs of Turkish Teachers in an Era of National Reforms. Australian Journal of Teacher Education, 41(1). Retrieved from: http://dx. doi.org/10.14221/ajte.2016v41n1.7.

Başak Kasa, Yasemin Ersöz (2016). Pros and Cons: Compulsory 12 year education reform in Turkey. South African Journal of Education, Vol 36, Number 2. Retrieved from: http://www.scielo.org.za/ scielo.php? script=sci_arttext\&pid=S0256-01002016000200009.

Tuba Gökmenoğlu, Christopher M. Clark (2015). Teachers evaluation of professional development in support of national reforms. Issues in Educational Research. Vol. 25(4), 442-459. Retrieved from: http:// www.iier.org.au/iier25/gokmenoglu.html. 